\title{
Media Manipulation 2.0: The Impact of Social Media on News, Competition, and Accuracy
}

\author{
By Neill Fitzpatrick ${ }^{*}$
}

\begin{abstract}
The term "media manipulation" has a double meaning. It is certainly possible to have a biased media outlet/organization manipulate the news and intentionally, or unintentionally, mislead the public but it can also be said that in this era of social media, the media itself can be manipulated and misled by individuals and organizations. Increasingly, there are examples of false information, retouched photographs, or edited video being released on social media. In many cases, this information goes "viral" in just days, even hours. When this happens, the competitive nature of journalism can lead to reporters and/or their supervisors feeling pressured to report it as news as soon as possible without first verifying its authenticity. The sophistication of social media platforms and their users means the speed at which information is disseminated has increased dramatically and continues to accelerate with the addition of new social media forms. I believe the accuracy of news is, at times, directly proportional to the speed with which the information spreads. My study examines primary and secondary research into this "double-edged sword" of media manipulation both from the perspective of the public and its concerns and from the perspective of journalists and their concerns about the significant impact on their profession of social media overall, and the manipulative exploitation of social media in particular. Based on an analysis of news articles, scholarly research, and social media content, I will advance recommendations for media researchers and scholars seeking to understand these issues and for journalists and news organization managers seeking to navigate them even as their embattled profession continues to evolve.
\end{abstract}

Keywords: accuracy, fake news, manipulation, media, social media.

\section{Introduction}

The issues of journalistic accuracy and public trust in journalists are not new. In recent years, however, these issues have been under renewed and intense scrutiny, as more and more people reject traditional media in favor of social media for their news consumption. In 2016, the startling political upheaval in the United States became an additional factor in the erosion of public trust in journalism. The rise of Donald Trump contributed to, even fueled, new concerns about manipulation of the media and the public due to his unfettered and unfiltered social media habit and to an unprecedented surge in so-called "fake news" stories spread to millions of people on various social media platforms. This study examined the existing and evolving profound impact of social media on journalism and news consumers as well as the implications for some longstanding communications theories. It employs a qualitative study of the events and reaction to the events during the six months between October 2016 and March 2017. The study also analyzed the reaction and response of journalists to what is arguably the most serious threat to their profession in history with interpretation and context aided by my personal experience and observations as a journalist for more than 30 years.

\footnotetext{
* Assistant Professor, MacEwan University, Canada.
} 


\section{Social Media is the Message}

Social media has irreversibly changed the world. In just over a decade, platforms such as Twitter, Facebook, Instagram, and Snapchat captured hundreds of millions of users around the globe, transformed our daily forms of communication with others, and provided unprecedented, almost instant, access to information, images, and opinions of all sorts, from around the world. While this constant flow of facts, fiction, even fantasy can be credited, or criticized, for many societal changes it can also be seen as a significant factor in the public's reception and perception of "news" in the general sense and, for many, the very definition of "journalism" in a broader perspective. Numerous studies indicate, with each passing year, that more and more people are finding and consuming news on social media platforms, primarily Facebook, as opposed to more traditional media forms such as radio, print, and television (Pew Research, 2016). This shift has led to a change in public perceptions of journalism. Growing numbers of news consumers now find and follow sources of news that are limited to what they "like" on their personalized Facebook feeds (Pew Research, 2016). Indeed, research shows that Facebook users seek out other views that align with their own. This selective news coverage can be informative but it can also create what has become known as an "echo chamber", a social media sharing experience that echoes one's beliefs and views to others and back (ElBermawy, 2016, para. 7). At the same time, a Facebook user's news feed and perspectives can be supplemented with information from sources they do not necessarily subscribe to personally. This is material that is passed on or visible on the pages of their Facebook "friends". These online contacts may actually be real-life friends or family members but the structure of Facebook means that any user's list of "friends" can also consist of distant relatives, acquaintances from years gone by, even complete strangers, all passing on viral videos, family photos, and news stories - both real and fake. This growing social media-only news perspective also contributed to an erosion of the public's trust in mainstream media. In fact, the trust level dropped to an "all time low" in 2016 (Swift, 2016). Distrust and confusion over news stories and news coverage also stemmed from an increase in the number and profile of "fake news" stories, especially in the months before and after the presidential election in the United States (Barthel, Mitchell \& Holcomb, 2016). This trend of obtaining news via social media and the intensified distrust in mainstream media was particularly noticeable between October 2016 and March 2017 as Donald Trump swept to power in the United States election and, subsequently, assumed control in the White House. Trump's victory, unexpected by many, may well have been thanks in part to his prolific use of Twitter and social media in the months leading up to the November 2016 election (Morin \& Grunwald, 2017, para. 7). After the election, Trump continued to confound his critics and frustrate the mainstream media by continuing to use Twitter on a daily basis. His unfiltered, uncensored tweets reached tens of millions of people, criticizing opponents and condemning high-profile mainstream media organizations as "fake news" (Trump, 2017a).

This study will analyze Donald Trump's status as the "Commander-in-Tweet" 
(Keith, 2016) in reference to his extensive use of social media. It will also examine the impact of Trump's Twitter activity/strategy social media activity, as well as that of his supporters, on the mainstream media and on the industry in general. It will discuss the future of journalism in light of President Trump's comments about, and treatment of, journalists after he was sworn in as president on January 20, 2017. In turn, the study will document the reaction, and actions, of journalists and media organizations in light of the actions, words, and tweets by Trump and his supporters. The initial complaints and outrage from journalists and news organizations' about the treatment has led to a "renewed sense of mission" (Grynbaum \& Ember, 2017, para. 6) among many journalists and a pledge to intensify the reportage of not only President Trump's actions but of important news stories in general.

\section{Research Problem}

This is a descriptive study of the impact of social media, in general, on journalism and, specifically, the impact of the criticism and treatment of mainstream media and journalists by political leaders and their supporters. It will analyze the factors contributing to the decline of accuracy in news reporting and the overall erosion of the public's trust in journalism.

\section{Research Question}

How can journalists overcome the negative affects of social media-fuelled manipulation and fake news to rebuild public trust and ensure the survival of the profession?

\section{Significance of the Study}

As a journalist for more than 30 years, I witnessed the slow, but steady deterioration of the news industry due primarily to economic factors brought on by the rapid development of online news and social media. Between 2012 and 2017, thousands of journalists were laid off due to downsizing in traditional media newsrooms across Canada and the United States (Doctor, 2015, para. 4). With fewer reporters to cover the stories, a perception grew that the quality of news coverage in many communities was suffering (Abramson, 2010, para. 3). The reduced resources forced those in charge of newsrooms, such as executive producers and assignment editors, to become more selective about which events and stories could be covered each day. Some events and stories simply had to be ignored because the depleted ranks did not allow for coverage. As a senior member of more than one newsroom, I believe this "pick and choose" type of news coverage was responsible for, at times, a skewed, less-informed perspective of a community for its news consumers. Fewer reporters also meant those who remained were called upon to do more each day. In my experience, this often translated to each reporter assigned daily to cover multiple stories or events and write and file stories or elements to multiple media platforms such as Twitter, Facebook, radio news, and television news. This increased workload, coupled with 
ongoing deadlines and fewer editors and supervisors, led to inaccuracies and errors in the news reports going out to consumers. However, despite the current state of journalistic affairs, this study will show that while journalism may be considered by some to be on "life support" (Kimble, 2017, p. 1), it is by no means dead. In fact, there are indications that, in North America at least, journalism may be on the verge of resurgence as news consumers look for quality, dependable sources of news (Edmonds, 2017, para. 2) in a marketplace that is increasingly distorted and blurred by shocking statements, headlines, and fake news stories.

\section{Limitations}

The research for this paper will focus primarily on six months beginning in October of 2016, as the presidential election campaign in the United States was in its final weeks, and ending in March of 2017 with Donald Trump in power in the White House. I will employ scholarly research, news articles and analysis from a variety of sources to illustrate and reinforce my key points, as well as material gleaned from social media platforms.

\section{Definitions}

Media manipulation. The Merriam-Webster dictionary definition of manipulation is "to manage or utilize skillfully" and "to control ... by artful, unfair, or insidious means especially to one's own advantage". ${ }^{1}$ The dictionary defines media as "the system and organizations of communication through which information is spread to a large number of people". ${ }^{2}$ Therefore, media manipulation can be defined as "to control the system and organizations of communication to one's own advantage".

While media manipulation has been interpreted in various ways in the past, this legal definition of the term may be one of the most complete and comprehensive: "the act of creating an image or argument that favors particular interests" (para. 1). ${ }^{3}$ This legal definition goes on to say that manipulation of the media can include the use of "logical fallacies and propaganda techniques" as well as "suppression of information or points of view". This definition also lists the strategy of "simply deviating attention elsewhere". Finally, the US Legal definition states: "It is often used as a powerful tool to manipulate masses through modern technologies". In this study, the term media manipulation is used to mean "the use of social media platforms to spread misleading or inaccurate misinformation".

In my experience as a journalist, there were two forms of media manipulation. There were cases of attempted manipulation by politicians and/or their communications or public relations staff. One standard effort involved a government department re-releasing information, such as budget spending, that had already been sent out to the media weeks or even months earlier. The goal was obvious: to generate new publicity and public discourse about an old topic.

Fake news. The dictionary definition of fake is "one that is not what it

\footnotetext{
${ }^{1}$ Merriam-Webster. Retrieved from https://www.merriam-webster.com/dictionary/manipulate.

${ }^{2}$ Merriam-Webster. Retrieved from https://www.merriam-webster.com/dictionary/media.

${ }^{3}$ US Legal, (n.d.). Retrieved from https://definitions.uslegal.com $/ \mathrm{m} /$ media-manipulation/.
} 
purports to be". ${ }^{4}$ The dictionary defines news as "a report of recent events" and "material reported in a newspaper or news periodical or on a newscast". 5 Therefore, fake news can be defined as "material reported in a newspaper or newscast that is not what it purports to be". Fake news is not a new phenomenon but it has become a key element of the current era of media manipulation. The website Webopedia defines fake news in this way: "Fake news, or hoax news, refers to false information or propaganda published under the guise of being authentic news" (para. 1). ${ }^{6}$ Another definition, from the PolitiFact website, highlights why fake news has taken on a entirely new meaning and significance in recent years: "Fake news is made-up stuff, masterfully manipulated to look like credible journalistic reports that are easily spread online to large audiences willing to believe the fictions and spread the word" (Holan, 2016, para. 2). While these definitions are relatively straightforward, fake news is not. In fact, the "made-up stuff" has become a profitable industry around the world because of easy access to social media and the ability to reach millions of people with one click of the mouse. For this study, fake news is used to mean "misleading or inaccurate information spread via social media as a way to manipulate the media and the public".

Accuracy. The dictionary defines accuracy as "freedom from mistake or error". ${ }^{7}$ In this study, accuracy is used in conjunction with the term news to mean "a report or recent events in a newspaper or newscast that is free from mistake or error".

Competition. Competition is defined in the Merriam-Webster dictionary as: "the act or process of trying to get or win something (such as a prize or a higher level of success) that someone else is also trying to get or win". ${ }^{8}$ In this study, competition will primarily be used in conjunction with the term news to refer to the efforts of a journalist or news organization finding and reporting a story or stories before another journalist or news organization is able to.

Social media: The dictionary defines social media as: "forms of electronic communication (as websites for social networking and micro blogging) through which users create online communities to share information, ideas, personal messages, and other content (as videos)". ${ }^{9}$ In this paper, references to the term social media will include various popular platforms such as Facebook and Twitter. At times, these platforms will be mentioned specifically but, in some cases, social media will be used as an all-inclusive term.

\footnotetext{
${ }^{4}$ Merriam-Webster. Retrieved from https://www.merriam-webster.com/dictionary/fake.

${ }^{5}$ Merriam-Webster. Retrieved from https://www.merriam-webster.com/dictionary/news.

${ }^{6}$ Webopedia. Retrieved from http://www.webopedia.com/TERM/F/fake-news.html.

${ }^{7}$ Merriam-Webster. Retrieved from https://www.merriam-webster.com/dictionary/accuracy.

${ }^{8}$ Merriam-Webster. Retrieved from https://www.merriam-webster.com/dictionary/competition.

${ }^{9}$ Merriam-Webster. Retrieved from https://www.merriam-webster.com/dictionary/socialmedia.
} 


\section{Literature Review}

In just over a decade, the advent, development, and rapid spread of social media ignited a renewed focus on interpersonal and mass communications. The social media explosion also initiated renewed examinations of some longstanding theories surrounding communications. Facebook, Twitter and other social media platforms altered how people receive messages and, in more and more cases, limited the width and breadth of those messages. For decades, much of the communications research held true as it focused on existing, traditional forms of mass communications such as print, then radio, and then television. The ongoing evolution of social media and its impact on interpersonal communications are significant factors in, and reasons for, a new assessment of several theories on communications and interpersonal relations.

\section{Manipulation 2.0}

Manipulation of the media and news is nothing new. Royalty in Europe appeared to understand the benefits of spreading their messages via the press as early as 1486. In England, King Henry VII capitalized on the relatively new printing press to distribute an announcement about his somewhat dubious claim to the throne (Stephens, 2007, p. 77). In France, Charles VIII made use of the press to communicate what he perceived as the positives of his invasion of Italy (Stephens, 2007, p. 77). Indeed, for centuries, many world leaders have recognized the merits of setting the agenda for the media and public to follow. American presidents are no exception to this practice. President Richard Nixon and his chief of staff H. R. Haldeman created the first White House communications office in an effort to "shape the President's public image" (Marshall, 2014, para. 7). Nixon was, in fact, a pioneer of media manipulation tactics: "Intimidating journalists, avoiding White House reporters, staging events for television - now common presidential practices - were all originally Nixonian tactics" (Marshall, 2014, para. 2). By 2016, manipulation of the media was commonplace and increasingly strategic in nature. The Economist labeled the phenomenon "post-truth politics" with this definition: "a reliance on assertions that "feel true" but have no basis in fact" ("Art of the Lie", 2016, para. 2). The analysis cited examples of "post-truth politics" by leaders in the United States, the United Kingdom, Turkey, and Poland. The evolution of "post-truth politics" transformed the theory of Agenda-Setting developed by Maxwell McCombs and Donald Shaw (1974). Their research found it was possible for the mass media to set the agenda for what the public thinks about because "we judge as important what the media judge as important" (McCombs $\&$ Shaw, 1974, p. 28). In other words, journalists had the power and influence to increase the significance and visibility of certain issues over others. In the post-truth era, politicians and others in positions of power have discovered that social media enables them to set the agenda for what the public thinks about. Donald Trump and others can bypass the media and use Twitter and other social media platforms to convey their messages, policies, and beliefs to millions of people. It is an audience that is growing. Donald Trump's Twitter following 
has nearly doubled in the months since he was elected. According to the Dutch company TwitterCounter, which describes itself as a third party application for Twitter, prior to the November 2016 vote, the Twitter account @ realDonaldTrump had approximately 13 million followers. On the day he was officially sworn in as president, January 20, 2017, his followers surpassed 21 million. By the end of February 2017, he had gained another four million followers. TwitterCounter predicted@realDonaldTrump will have more than 66 million followers by the end of 2018. The figures allow TwitterCounter to describe the @ realDonaldTrump Twitter account as "within celebrity status" (TwitterCounter, 2017). Trump's Twitter usage appeared to many as random but at least one scholar believed it was very much a strategic way to manipulate the media and set an agenda. Linguist and professor emeritus George Lakoff tweeted "A Taxonomy of Trump Tweets" to the world to illustrate what he believes is a four-part social media strategy. "Preemptive Framing" involves "being the first to frame an idea" (Lakoff, 2017). Lakoff's example is Trump's tweeted allegation that the cyber attacks of the Democratic National Committee were its own fault. Another example could be Trump tweeting that his phone lines were ordered tapped by former President Barack Obama in the days before the 2016 election:

Donald J. Trump

@ realDonaldTrump

How low has President Obama gone to tapp my phones during the very sacred election process. This is Nixon/Watergate. Bad (or sick) guy! (Trump, 2017b, March 4).

The unexpected, unexplained allegation was re-tweeted nearly 50,000 times in less than 24 hours. It triggered a firestorm of controversy and, despite demands by media outlets, neither Trump or the White House provided any additional details, much less any evidence of the wiretapping. Lakoff's second category is "Diversion", as in "Divert attention from real issues". The example cited is the January 9, 2017 attack on actress Meryl Streep by the president as questions about conflicts of interest and hacking by Russia swirled around him. The wiretap allegation against Barack Obama could be included in this category, as well. Next is "Deflection" as in "attack the messenger, change direction". The messenger, in most cases, is the media and Lakoff summarized this ploy as part of Trump's efforts to erode public trust in the media, reframe stories as "fake news", and "establish (the) Trump administration as (a) source of truth". The final category in Lakoff's analysis is the "Trial Balloon", designed to test the public's appetite for ideas and policies with the example a December 2016 tweet by Trump that focused on nuclear arms escalation:

Donald J. Trump

@ realDonaldTrump

The United States must greatly strengthen and expand its nuclear capability until such time as the world comes to its senses regarding nukes (Trump, 2016, December 22). 
Random or strategic, Trump's online behavior spawned comparisons to other world leaders - comparisons that are not positive. Russian dissident and pro-democracy activist Garry Kasparov likened the American president's nuclear rhetoric to that of his Russian counterpart on another global issue: "It mirrors Putin's bombastic rhetoric as he produces his own deadly reality show in Syria" (Kasparov, 2016, para. 7). The evolution and impact of social media created a new era of agenda-setting and narrative framing. It empowered world leaders, celebrities, and average citizens to bypass the traditional mass media gatekeepers and frame stories and discourse on their own terms.

\section{Fake News and the "New Shape of Truth"}

"The major new challenge in reporting news is the new shape of truth" (Gray, 2017, para. 16). This statement, from Kevin Kelly of Wired magazine in March 2017, accurately summarized the challenge facing both journalists and news consumers in the social media era. The "truth" is becoming more difficult to determine because "for every fact there is a counterfact" (Gray, 2017, para. 16). In some cases, the counterfacts were persuasive enough to effectively undermine the truth. In the final months of 2016, a rumor about an alleged child sex ring operating in a Washington, D.C. pizza restaurant appeared on Twitter. The rumor implicated Hillary Clinton in the sex ring and the initial tweet was quickly retweeted thousands of times. It then spread to other social media platforms, reaching hundreds of thousands of people around the world in just weeks (Fisher, Cox, Hermann, 2016, para. 8). One of them, Edgar Welch, so believed the story that he armed himself with an assault rifle and drove hundreds of miles to rescue the abused children from the pizza restaurant. Welch fired some shots inside the restaurant. Fortunately, no one was injured and Welch was arrested (Fisher et al., 2016, para. 2). "Pizzagate" was a fake news story, like so many others on the internet but one that gained more attention than most. Fake news is not limited to North America. A few weeks after the "Pizzagate" gun threat, a fake news story prompted a threat of nuclear proportions by Pakistan's defense minister. On Twitter, Khawaja Muhammad Asif wrote "Israel forgets Pakistan is a Nuclear state too" in what appeared to be a reaction to a false story on a website that alleged Israel had threatened Pakistan with nuclear weapons (Goldman, 2016, para. 2). In China, newspapers used the term "fake news" for the first time in March 2017 as the state media reacted to allegations of government torture by a prominent rights activist (Shepherd, 2017, para.1). One researcher linked the Chinese use of the term to Donald Trump's ongoing attacks on Western media organizations (Shepherd, 2017, para. 7). Fake news, rumors, and gossip are not new issues for society but the falsehoods took on a new significance with the advent of social media and, it seems, a new resonance with the public. In fact, nearly two-thirds of American adults surveyed said fake news stories "cause a great deal of confusion" about the facts of news stories and current events (Barthel et al., 2016, para. 2). The same survey by the Pew Research Center found almost one-quarter of adults admitted to sharing a fake political story online. Some, about $16 \%$, did it "inadvertently" without knowing it was not true but roughly the same number of adults, $14 \%$, shared online what they knew was a fake political story 
(Barthel et al., 2016, para.13). Their reasons included intentionally wanting to spread fake news, to bring attention to the fake stories, or simply for "amusement" (Barthel et al., 2016, para. 15). Why do so many people believe rumors and innuendo? It may be linked to what is known as "belief perseverance". This theory purports that many people hold on to new beliefs "even if they are informed that the initial information on which those beliefs were based was incorrect" (Green \& Donahue, 2011, p. 315). This "belief perseverance" strengthens if the individuals have "integrated those beliefs into their knowledge" (Green \& Donahue, 2011, p. 315). Green and Donahue's research suggests that, especially in the "post-truth" era, once a false story is online or published it may be too late to retract it, correct it, or negate its impact. Additionally, there is an inherent trust that exists among many that, by and large, people are honest and will tell the truth. This "truth bias" factors into the power and influence of fake news stories. Individuals may tend to believe the story, or facets of the story, because of the implied "social contract" that dictates we will be honest with one another (McCornack \& Parks, 1986, p. 380). Not only are journalists and the public called upon to decipher fact from fiction with news stories, they also contend with fake news disguised as advertising, public relations, and medical "breakthroughs". It has become known as "astroturfing", an often-sophisticated practice that involves products or causes with what appears to be support from grassroots and community movements. In reality, the product or cause is conceived or funded by corporations. The grassroots are fake, thus the term "astroturfing" (Attkisson, 2014). Sharyl Attkisson is an American journalist who has investigated the growth of astroturfing and, specifically, how corporations target mainstream media in an effort to garner publicity. Attkisson's research found that the truth is masked as the messages are communicated through online blogs, letters to editors, and seemingly grassroots Facebook and Twitter accounts. Too often, says Attkisson, the bogus movement then jumps to the next level as the story or cause is picked up and covered by mainstream media outlets. "Astroturf's biggest accomplishment is when it crosses over into semi-trusted news organizations that unquestioningly cite or copy it" (Attkisson, 2014, para. 4). In reaching the general public, those who "planted" the astroturf initially reaped the benefits.

\section{Journalism under Siege}

In 2017, "fake news" evolved into more than just a label for misleading, inaccurate news stories. It became an adjective to modify "journalism", in general, and many mainstream media organizations, in particular, thanks in large part to US President Trump and his tweets. Trump repeatedly called out the New York Times, NBC News, CNN, and others as the "fake news media" (Trump, 2017a). His almost-daily Twitter tirades also raised questions for his 26 million followers about the fairness and accuracy of the media when he branded the New York Times and other mainstream media as "the enemy of the people" (Trump, 2017a). The Trump campaign team followed this with its Mainstream Media Accountability Survey that was sent out to supporters. The 25 questions focused on a number of issues but most, if not all, centered on media bias against the president and trust in the media. Question \#24 defined what the media produces as "noise": 
"Do you agree with President Trump's media strategy to cut through the media's noise and deliver our message straight to the people?"10

The survey drew criticism for its "loaded" and "confusing" questions and for an unscientific design that could help confirm a desired hypothesis (Vlasits, 2017, para. 2). This ongoing "fake news" framing strategy served to reinforce the growing public perception of a mainstream media that could not be trusted.

\section{Accuracy in the Age of Speed-Driven Journalism}

Journalism has always been scrutinized for accuracy issues. At times, the accuracy is compromised by the competitive nature of journalism. Competition is a factor in driving journalists to "break" a story before anyone else is able to. This "thirst to be first" can come at the expense of details of the story, even some facts of the story. Some journalism organizations have strict policies on ensuring the story is complete and completely accurate before publishing or airing but others do not or have policies less stringent.

In Canada, the Canadian Broadcasting Corporation (CBC) has a longstanding motto that states: "It's more important to be right, than to be first". The organization reinforces that motto with a policy that demands each story, and each element of the story, to be "double-sourced" before it is reported. This is how the process is explained in the CBC's Journalistic Standards and Practices document: "Our commitment to accuracy and integrity means we try where possible to verify the information with a second source. And there may be times when more than two sources are required. Our stories are based on information we have verified. Wherever possible, our stories use first hand, identifiable sources-participants in an event or authenticated documents". ${ }^{11}$

In my experience as a journalist in Canada for more than 30 years, I believe this double-sourcing policy is the exception and, generally, not the rule for media organizations in Canada and the United States. This issue of competition, speed, and accuracy is exacerbated in the era of social media (Reinardy, 2010, p. 79). The constant news cycle on Twitter, Facebook and other platforms has largely eliminated the hard and fast deadline of old. Journalists are now pressured to deliver the news throughout each day as opposed to the traditional "end-ofthe-day" deadline. This constant news flow creates a constant pressure on journalists not only to deliver a story but to deliver it, in pieces, as the story develops (Fisher, 2014, para. 25). In my role as a news executive producer, I routinely urged reporters to tweet from news conferences and breaking news locations. They were told to take photos and video with their cell phones and post the images on social media as soon as possible or, at least, before their competition did. All this before the journalist was able to return to the newsroom to write and file their complete story. Reporters are also called upon to deliver live reports from the scene on radio or television broadcasts. Again, these live reports are generally composed of the details the journalist knows at the time

${ }^{10}$ Mainstream Media Accountability Survey. (2017). Retrieved from goo.gl/xWafjj.
${ }^{11}$ CBC Journalistic Standards and Practices. (n.d.). Retrieved from: goo.gl/hTbujp. 
and supplemented by what witnesses may have seen or heard. As a result, some or all of the information relayed to the public on radio or television newscasts and on social media can be incomplete, misleading, or completely wrong. Still, it seems in the age of the so-called "YouTube generation", accuracy and the truth can take a back seat to getting the story online as soon as possible with the facts that are available. In the words of one ABC News editor-in-chief: "It's dirty and it's not always right, but it's instantaneous" (Fisher, 2014, para. 37).

\section{Social Media Solitary Confinement}

With growing concerns about trust and accuracy, it is little wonder more and more individuals are turning to social media to find and consume their news. The primary source for millions of people has, in recent years, become Facebook. A study by the Pew Research Centre in January of 2016 found that $62 \%$ of American adults receive their news on social media, up substantially from 49\% in 2012 (Pew Research, 2016). The most commonly used platform for finding news is Facebook. The study found $66 \%$ of Facebook users said they relied on the site for their news (Pew Research, 2016). In addition, nearly two-thirds (64\%) of adults surveyed used only one social media platform for news and it is most commonly Facebook (Pew Research, 2016). The convenience of Facebook is certainly a factor in its growth as a news source. The growing dependence by so many on Facebook as a sole source of news is a factor in creating a narrowed perspective on news and world events. The Facebook "echo chamber" provides only a limited perspective because it is built on the user's likes, dislikes, and beliefs as well as those of the user's Facebook friends. Other opinions are ignored as we select and share only what relates to our "specific narrative" (Del Vicario, et al. 2016, para. 34). Around the world, the more than 1.6 billion personalized Facebook echo chambers become our "internet islands" that grow more and more "segregated and sound proofed" against educated or opposing views: "... and as a result we eventually become victims to our own biases" (El-Bermawy, 2016, para. 7). The amount of time individuals spend inside their echo chambers is increasing. From 40 minutes a day in 2014 to an average of 50 minutes a day in 2016 (Stewart, 2016, para. 3). Fifty minutes is more time than what is spent on reading, exercise, or social events. In fact, Facebook's 50 minutes is closing in on how much time people spend eating and drinking. Although, it is still well below time spent watching television (2.8 hours/day on average) (Stewart, 2016, para. 5). George Gerbner's Cultivation Theory stemmed from his 1976 research on the effects of television violence on those who watch it. What they see on the screen can "cultivate" their perceptions and beliefs. Gerbner viewed television as society's storyteller and the stories it emitted "a coherent picture of what exists" and "what is important" (Gerbner \& Gross, 1976, p. 176). Gerbner used the term "mainstreaming" to describe the process of "commonality" of values and outlooks that people with heavy TV viewing habits can experience (Gerbner, Gross, Morgan, \& Signorielli, 1982, p. 104). He found that constant exposure to the same images and labels leads to a "convergence of attitudes on issues of personal morality" (Gerbner et al., 1982, p. 117). One could argue that, 40 years later, social 
media has become the societal storyteller for many people. Our growing exposure through Facebook to like-minded images, labels, and news stories can create a commonality of outlook similar to Gerbner's theory surrounding televisioninduced homogenized values. However, in the social media era, it happens more quickly. The structure of Facebook and our ability to quickly and easily share views and news, real or fake, with many others accelerates cultivation and mainstreaming and erects new echo chambers every day.

\section{Methodology}

\section{Research Methodology}

This was a qualitative research method that applied a historical analysis of news stories, opinion articles, and social media content from a six-month period beginning in October 2016 and ending in March 2017. The period selected coincided with the final weeks of the United States election campaign and the first few months of the Trump administration in power. The news stories and opinion or analysis articles were found on the websites of numerous mainstream media organizations including the New York Times, NBC News, ABC News, The Guardian, The Independent, the Canadian Broadcasting Corporation (CBC), and the British Broadcasting Corporation (BBC). In addition, the analysis focused on Twitter, in general, and Donald Trump's Twitter feed specifically, to isolate instances of criticism of journalism and the reaction to the criticism. This material was supplemented with theories and research found in various academic papers and scholarly journals published over the past 70 years. To identify the growing prevalence and increased public awareness of terms such as "fake news", and "media manipulation", a Google search of news articles containing these specific words and others was conducted. The research also utilized unobtrusive observation, based on my experience as a journalist, to examine the emergence and impact of media manipulation efforts during the six-month period as well as the proliferation of online fake news stories during that time.

\section{Findings/Results}

By examining the frequency of certain keywords appearing in news stories and social media between October 2016 and March 2017, insights into journalism and the public perception of journalists can be observed. As illustrated in the following table, the term "fake news" was found more than 8.1 million times in news articles between October 1, 2016 and March 31, 2017. The words "journalism" and "trust" appeared nearly 1.4 million times while "media" and "manipulation" were found in excess of one million times. In contrast, the words "journalism" and "accuracy" surfaced just 55,800 times (Table 1). 
Table 1. World Frequency Analysis

\section{Word Frequency Analysis}

Google Search of News Articles - October 1, 2016 - March 31, 2017

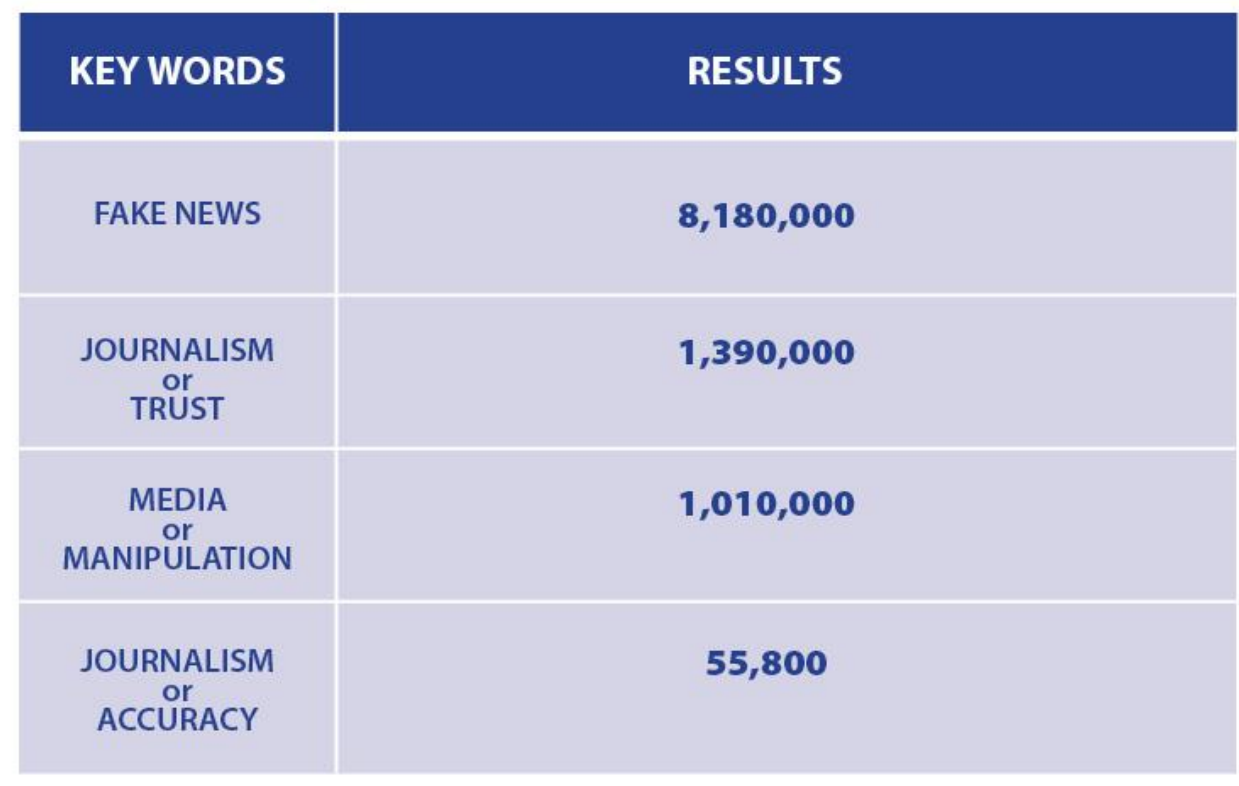

Source: Google.ca. (2017). Retrieved from http://www.google.ca.

\section{Discussion}

The results are an indication of the soaring interest in fake news and its impact by both journalists and the public in the weeks before and immediately after the November US presidential election. An analysis of the same sixmonth period from one year earlier, October 1, 2015 to March 31, 2016, revealed much different findings. The "fake news" search, for example, yielded 660,000 results - still a significant figure but a fraction of the 2016-2017 results. The other corresponding figures were also significantly lower. Clearly, the massive, unexpected political shift in the United States had a dramatic impact around the world, raising the profile of fake news, misinformation, and propaganda to unprecedented levels. Growing usage of social media by consumers to find and share "real" news is also a contributing factor because Facebook and other platforms have become key sources for finding and spreading misinformation, both unknowingly and intentionally. Almost a third (32\%) of American adults surveyed by the Pew Research Center said they "often" see fake political news online (Barthel et al., 2016, para. 9). More than half (51\%) said they often see news "that is not fully accurate" (Barthel et al., 2016, para. 10). Perhaps most telling is that nearly one-quarter $(23 \%)$ of the US adults surveyed admitted to sharing "fabricated news" either knowingly or unknowingly (Barthel et al., 2016, para. 13). 


\section{Conclusion}

The growth of social media usage around the world shows no signs of slowing. This growth, along with new innovations, will continue to affect many facets of society, including interpersonal communication, news consumption, and journalism. Thus, a review of some long-standing communications theories is warranted to factor in the implications of social media. The Cultivation Theory, for example, was researched and designed decades ago around television content and viewing habits. With social media now the daily habit for so many, the new question is: how does the material shared and found on Facebook, Twitter, and other platforms "cultivate" our views and beliefs over time? This research also lays a foundation for a renewed analysis of the impact of social media on journalism and the public's perception of journalists. As the number of Facebook users increases, so will the number of people who look for and receive their news primarily, even solely, on Facebook. This has implications of creating more narrow perspective "echo chambers" and further alienating the public from the mainstream media. As a journalist, I am optimistic the industry will survive the tumult of social media, the struggling economy, and the public's distrust. To do so, however, it will require a back-to-basics approach to reporting, one that avoids the accuracy pitfalls of the "thirst-to-be-first" competition-driven model, which, in my experience, does little to attract a new audience or impress the existing audience. It seems clear that in the post-truth era there are still news consumers who value the truth and, in fact, demand it because it has become more elusive. Indeed, there is some evidence of this, such as the increased subscriptions for the New York Times in the weeks following the US election. For their part, media organizations are creating or expanding fact-checking resources to regain and retain the public trust by way of focusing on the confirmation of information found online. In some cases, this quest for the truth is convincing even competitors to work together. In Norway, concerns about inaccuracies and public trust of the media prompted an unprecedented collaboration of the nation's public broadcaster and its two largest online news sources. NRK, VG, and Dagbladet created a team of journalists that will research stories and operate as a separate non-profit entity (Mantzarlis, 2017). In France, more than three dozens news organizations are employing a "strength in numbers" approach to weeding out fake news. The CrossCheck project enables dozens of journalists in competing newsrooms to share information on stories and social media posts that require more scrutiny. The stories are researched and then given a "true" or "false" label by the CrossCheck participants (Davies, 2017, para. 7). In Ukraine, the fake news fight has been led by the StopFake.org website. It was launched in 2014 by lecturers, students and graduates at the Kyiv Mohyla Journalism School to "refute disinformation and propaganda" emanating from the Kremlin. ${ }^{12}$ The website and the team behind it has since expanded to shed light and provide context on stories emerging in Syria, Turkey and other nations. For example, StopFake.org raised awareness of the social media-fuelled growth of the far-

\footnotetext{
${ }^{12}$ StopFake.org. Retrieved from http://www.stopfake.org/en/news/.
} 
right political Freedom Party in Austria, likening the leader to Donald Trump because he, too, bypasses the traditional media to communicate directly with voters by way of Facebook. Stop Fake urges its Facebook and Twitter followers and anyone who finds fake news or information to submit it for a "truth autopsy". On April 2, 2017 the first International Fact-Checking Day took place. It was declared by the International Fact-Checking Network (IFCN), a forum for fact-checkers around the world organized in 2015. April 2 was chosen by the IFCN, intentionally, because it follows April Fools' Day. The goal of FactChecking Day was to raise awareness of "misinformation in all its forms" and "enlist the public in the fight" against that misinformation (Mantzarlis, 2017). The concerns over the impact of fake news have extended beyond journalism to include calls for improved education of the younger generation. Despite growing up using social media, a Stanford University study found a "dismaying" inability by high school and college students to identify false information in tweets and articles (Domonoske, 2016, para. 7). The lead author of the study believes young people need to be educated "to read like fact checkers" (Domonoske, 2016, para. 34). Indeed, the website for International Fact-Checking Day was designed with a multi-language school lesson plan to enable teachers to help teens "navigate through an ocean of information, rumors, hoaxes, and lies". ${ }^{13}$ Additionally, the Organisation for Economic Co-operation and Development (OECD) is lobbying for new initiatives in schools to teach young people how to identify fake news stories. The OECD said the ability to separate factual stories from fiction is "essential in the modern age" and believes teachers are well suited to provide the required instruction (Siddique, 2017, para. 2).

It is perhaps fitting that the final word in this study is from the US Press Corps, which includes the White House journalists at the center of the posttruth era assault on the profession. A few days before the 2017 presidential inauguration, the Press Corps sent an open letter to the president-elect. The intent of the letter was to "clarify ... the relationship" between the journalists and the Trump administration and detail how the journalists planned to cover the new president over the next four years (Pope, 2017, para. 10). The letter pledged to hold Donald Trump to the "objective truth" when he or his surrogates "say or tweet something that is demonstrably wrong" (Pope, 2017, para. 8). The communique closes with the journalists expressing gratitude to Donald Trump because he "forced us to rethink the most fundamental questions about who we are and what we are here for" (Pope, 2017, para. 12). It is this approach and this attitude - an essential self-examination - that all journalists must embrace if there is any hope of journalism regaining the trust of the public and remaining a viable source of information in the social media dominated age.

\footnotetext{
${ }^{13}$ Poynter.org (2017). Lesson plan | FactChecking Day. Factcheckingday.com. Retrieved from goo.gl/qONRcv.
} 


\section{References}

Abramson, J. (2010). Sustaining Quality Journalism. Retrieved from goo.gl/pWHmtv. Art of the Lie. (2016). The Economist. Retrieved from goo.gl/fGHQpG.

Attkisson, S. (2014). What's most successful when it appears to be something it's not? Astroturf. As in fake grassroots. Retrieved from goo.gl/zbCZz2.

Barthel, M., Mitchell, A, \& Holcomb, J. (2016). Many Americans believe fake news is sowing confusion. Retrieved from goo.gl/aBlv1h.

Davies, J. (2017). European newsrooms are forming a united front against fake news. Digiday. Retrieved from goo.gl/TL2KZz.

Del Vicario, M., Bessi, A., Zollo, F., Petronic, F., Scala, A., Caldarelli, G., Stanley, H., \& Quattrociocchi, W. (2016). The spreading of misinformation online. Proceedings of the National Academy of Sciences. Retrieved from goo.gl/ycD4DR.

Doctor, K. (2015) Newsonomics: the halving of America's daily newsrooms. Retrieved from: goo.gl/TU9eV4.

Domonoske, C. (2016). Students have "dismaying" inability to tell fake news from real, study finds. Retrieved from goo.gl/a912Gk.

Edmonds, R. (2017). Trump bump subscription surge brightens otherwise grey results at New York Times. Retrieved from goo.gl/5Eioie.

El-Bermawy, M. (2016). Your filter bubble is destroying democracy. Retrieved from: goo.gl/19xjKS.

Fisher, M. (2014, March 3). Who cares if it's true? Modern-day newsrooms reconsider their values. Retrieved from goo.gl/Nmm6s5.

Fisher, M., Cox, J., Hermann, P. (2016). Pizzagate: From rumor, to hashtag, to gunfire in D.C. Washington Post. Retrieved from goo.gl/UW43pg.

Gerbner, G. \& Gross, L. (1976). Living with television: the violence profile. Journal of Communication, 26(2), 172-194.

Gerbner, G., Gross, L., Morgan, M., \& Signorielli, N. (1982). Charting the mainstream: television's contributions to political orientations. Journal of Communications, 32(2), 100-127.

Goldman, R. (2016). Reading fake news, Pakistani minister directs nuclear threat at Israel. Retrieved from goo.gl/sFfVhQ.

Gray, R. (2017, March 1). Lies, propaganda and fake news: a challenge for our age. Retrieved from goo.gl/XTCUJQ.

Green, M. \& Donahue, J. (2011). Persistence of belief change in the face of deception: the effect of factual stories revealed to be false. Media Psychology, 14(3), 312-331.

Grynbaum, M. \& Ember, S. (2017). Journalists, battered and groggy, find a new sense of mission. Retrieved from goo.gl/csZEQk.

Holan, A. (2016). 2016 Lie of the year: fake news. Retrieved from: goo.gl/aCSB02.

Keith, T. (2016). Commander-in-Tweet: Trump's social media use and presidential media avoidance. Retrieved from goo.gl/oPva5d.

Kasparov, G. (2016) Donald Trump reminds me of Vladimir Putin - and that is terrifying. Retrieved from goo.gl/UnYgGf.

Kimble, H. (2017). Journalism: on life support and in critical condition. Retrieved from goo.gl/YvgvRB.

Lakoff, G. (2017). A Taxonomy of Trump Tweets. Twitter. Retrieved from goo.gl/9bbg GE.

Marshall, J. (2014). Nixon is gone but his media strategy lives on. Retrieved from goo. $\mathrm{gl} / \mathrm{cxGU} 93$. 
McCombs, M. \& Shaw, D. (1974). A progress report on agenda-setting research. Paper presented at the Annual Meeting of the Association for Education in Journalism (57th, San Diego, California, August 18-21, 1974). Retrieved from goo.gl/Cpjeuj.

McCornack, S. \& Parks, M. (1986). Deception detection and relationship development: the other side of trust. Communication Yearbook, 9, 380.

Mantzarlis, A. (2017). Rivals become partners in Norway's newest fact-checking project. Poynter. Retrieved from goo.gl/MVLG8a.

Morin, R. \& Grunwald, M. (2017). Trump says social media was key to victory. Politico. Retrieved from goo.gl/TXZOpn.

Pew Research. (2016). News use across social media platforms. Retrieved from: goo. $\mathrm{gl} / \mathrm{KM} 3 \mathrm{YNV}$.

Pope, K. (2017, January 17). An open letter to Trump from the US press corps. Columbia Journalism Review. Retrieved from goo.gl/QxkhNh.

Reinardy, S. (2010). Need for speed onto Internet clashes with journalistic values. Newspaper Research Journal, 31(1), 77-81.

Shepherd, C. (2017). China dismisses human rights activists' torture claims as "fake news". Retrieved from goo.gl/bqVqsT.

Siddique, H. (2017). Teach schoolchildren how to spot fake news, says OECD. The Guardian. Retrieved from https://amp.theguardian.com/media/2017/mar/18/tea ch-schoolchildren-spot-fake-news-says-oecd

Stephens, M. (2007). A history of news (3rd ed.). New York: Oxford University Press.

Stewart, J. (2016). Facebook has 50 minutes of your time each day. It wants more. Retrieved from goo.gl/WQZZmN.

Swift, A. (2016, September 14). Americans' trust in mass media sinks to new low. Retrieved from http://news.gallup.com/poll/195542/americans-trust-mass-mediasinks-new-low.aspx

Trump, D. (2016). The United States must greatly strengthen and expand its nuclear capability. Twitter. Retrieved from goo.gl/22Tb8f.

Trump, D. (2017a).The FAKE NEWS media (failing@nytimes, @NBCnews, @ABC, @CBS, @CNN) is not my enemy, it is the enemy of the American people! Twitter. Retrieved from goo.gl/uXwucT.

Trump, D. (2017b). How low has President Obama gone. Twitter. Retrieved from goo. gl/imKASf.

TwitterCounter. (2017, March 2). @ realDonaldTrump Twitter account. Retrieved from https://twittercounter.com.

Vlasits, A. (2017). Trump made a media survey that's more rant than science. Retrieved from goo.gl/xmo23J. 
